\title{
Convenções de interfaces digitais e leitura ou: para ler interfaces nos textos
}

\author{
Digital interface and reading conventions or: to read interfaces \\ on texts
}

\author{
Ana Elisa Novais ${ }^{a}$ \\ a Instituto Federal de Minas Gerais, Ouro Preto, Minas Gerais, Brasil - anaelisanovais@gmail.com
}

Palavras-chave: Leitura. Navegação. Interfaces Digitais. Convenções de Interface.

Keywords: Reading. Navigation. Digital Interfaces. Interface Conventions.
Resumo: Um movimento que transporta convenções de interfaces digitais (botões, janelas, mensagens de sistema, ícones, entre outros) para textos impressos é o fenômeno em foco neste trabalho. Inicialmente, discuto a importância cultural das interfaces digitais em três dimensões: pensando-as como diálogo, como mídia remediada e como sistema semiótico específico, constituído de convenções que lhe são próprias. Em seguida, analiso seis textos que usam convenções de interface em sua composição multimodal, buscando, em diálogo com estudos e categorias do Design de Interação, elementos para esclarecer quais questões são essenciais na compreensão do que se espera do leitor hoje, com esses textos e essas novas formas de produzir sentido.

Abstract: A movement that carries conventions of digital interfaces (buttons, windows, system messages, icons, among others) is the phenomenon in focus in this work. First, I discuss the cultural importance of digital interfaces in three dimensions: thinking of them as dialogue, as remediated media, and as specific semiotic system, with its' own conventions. Then, I analyze six texts that explore interface conventions in their multimodal composition using categories of Interaction Design. Their elements and models helps to clarify which questions are essential in understanding what is expected of the reader today, with these new texts and these new ways of making sense. 


\section{INTRODUÇÃO}

Desde Ribeiro (2008), entendemos que ler e navegar são operações distintas no processo de produção de sentidos. Em meios impressos, algumas convenções da ordem do navegar, são, por exemplo, sumários, índices, paginações, alguns elementos de design e do projeto gráfico. Nos ambientes digitais, hiperlinks, janelas, botões, menus, mensagens de sistema, barras de rolagem e de progresso são exemplos de convenções que operam a navegação digital, nas mais diversas experiências - da cópia de um arquivo entre dispositivos de memória à interação em redes socais.

O movimento que a pesquisa geradora deste artigo detectou é que passamos a deslocar, como produtores de textos, as convenções de interfaces digitais da ordem da navegação para a ordem da leitura. Ao invés de atuar como elementos de navegação para sistemas digitais, os botões, ponteiros do mouse, janelas, barras de rolagem, mensagens de sistema e outras convenções de interfaces estão sendo usados na composição de textos multimodais.

Ferreiro (2001) nos lembra que, apesar de usarmos "ler" como o verbo para denominar $o$ ato da leitura, o que se espera do leitor muda ao longo do tempo. Com a emergência desse novo fenômeno cultural-semiótico, que é a presença de convenções de interfaces digitais nos mais variados textos, precisamos compreender o que são interfaces digitais, qual sua importância cultural, quais são suas convenções e como atuam na produção de sentidos.

Neste artigo, discuto essas questões buscando diálogos interdisciplinares no Design de Interação. Serão analisados seis textos representativos deste movimento de deslocamento das convenções de interfaces dos ambientes digitais para os textos, pensados na perspectiva de Colusso (2014), pesquisador da Ciência da Computação que usa a Teoria da Metáfora Conceptual para definir a figuratividade das interfaces digitais em termos de a) superfícies e objetos; b) manipulação e acesso; c) processos.

Mas de que interface estamos falando? O que estou chamando de interfaces? A seguir, apresento alguns apontamentos que podem ajudar a esclarecer essas perguntas.

\section{A IMPORTÂNCIA CULTURAL DAS INTERFACES DIGITAIS}


Somos contemporâneos da emergência de sistema de representação responsável por traduzir códigos computacionais e processamentos digitais em informação coerente e acessível a uma escala humana de compreensão. Esse trabalho criativo, imaginativo e inédito, ao mesmo tempo em que modifica nossa paisagem comunicacional, oferece incrementos para nossos processos cognitivos.

Steven Johnson (2001, p. 4) propõe que “[...] o trabalho de representar informação digital na tela deveria ser visto como a forma simbólica de nossa era". As interfaces digitais, “[...] mundo imaginário de alavancas, canos, caldeiras, insetos e pessoas conectadas - amarradas entre si pelas regras que governam esse pequeno mundo" (JOHNSON, 2001, p. 4), são enquadramentos que restringem e propulsionam nossas experiências, assim como fizeram as grandes catedrais na Idade Média, o desenho em perspectiva no Renascimento, o cinema, a televisão.

Para o escritor norte-americano, as interfaces digitais, as catedrais góticas e o romance vitoriano têm em comum a perspectiva do "espaço-informação", sistema de signos que funciona em diferentes escalas - desde a organização do espaço e seus objetos até as funções atribuídas a eles. Esses sistemas seriam criados para tornar imagináveis realidades invisíveis. Criar metáforas para interfaces é, para Johnson, um trabalho análogo ao de artistas como James Joyce, Charles Dickens ou os renascentistas, que, cada um em seu tempo, formataram nossa percepção sobre o mundo.

Comparar a criação das interfaces digitais a um trabalho artístico pode não fazer tanto sentido hoje, quando os processos de produção seguem heurísticas cientificamente testadas, e os maiores proprietárias de interfaces são empresas privadas que visam ao lucro e detêm todos os direitos de produção e criação. Mas é inegável a influência das tecnologias digitais em nossas práticas cotidianas e em nossa forma de ver o mundo. A digitalização da cultura, nas suas mais variadas dimensões, é um processo que cresce exponencialmente e cuja capilaridade alcança diversos domínios da atividade humana.

Para além da discussão sobre a natureza artística dos elementos de interfaces digitais, o pensamento de Johnson nos ajuda a compreender a importância cultural, simbólica e cognitiva das interfaces digitais e dos sistemas de informação, criados para aproximar o processamento digital de uma escala humana de compreensão. Importância essa atestada por outros autores, como Manovich (2001, p. 66), que considera as interfaces 
um "código semiótico chave", que afeta e é afetado pelo funcionamento de objetos culturais em geral.

A natureza das interfaces digitais é metafórica porque seu trabalho é interfacear: "[...] articular, transportar, difratar, interpretar, desviar, transpor, traduzir, trair, amortecer, amplificar, filtrar, inscrever, conservar, conduzir, transmitir ou parasitar" (LÉVY, 1993, p. 181-182). As metáforas conceptuais atuam como interfaces: membranas, películas, operando interfaceamentos (projeções, mapeamentos) entre domínios conceptuais.

Interfaces são vistas como membranas, pontos de contato que, ao mesmo tempo, permitem e constrangem o acesso à máquina. $\mathrm{Na}$ verdade, existem diferentes camadas de interfaces. Segundo Boomen (2014), essa rede de relações é operada em pelo menos cinco fronteiras: a) interface entre hardware e usuários (mouse, tela, teclado); interface entre hardware e outro hardware (slots, conectores); b) interface entre hardware e software (sistemas operacionais e drivers de dispositivos); c) interface entre software e software; d) símbolos, softwares e usuários (comandos icônicos e textuais).

Outra proposta de compreensão desta rede de relações e interfaceamentos está em Signorini e Cavalcanti (2010). Ao estudarem relações entre língua, linguagem e mediação tecnológica, as autoras lembram que movimentos de tradução, transformação e passagem evocam:

[...] um modelo de estrutura topológica em que sistemas simbólicos, ou linguagens, estão dispostos em camadas descontínuas e heterogêneas: na base, a linguagem numérica ou "de máquina", em seguida a linguagem de programação ou código, e, no nível mais alto, a linguagem de interface de usuário (linguagem natural, gráfica, imagética, sonora, hipermidiática). (SIGNORINI; CAVALCANTI, 2010, p. 432).

As chamadas "interfaces de usuário", com as quais interagimos mais comumente, seriam a última fronteira de relações descrita por Boomen (2014) ou ainda essa camada “de nível mais alto" proposta por Signorini e Cavalcanti (2010), não ignorando relações fronteiriças entre diferentes camadas.

\section{INTERFACES DIGITAIS NO DOMÍNIO DA LINGUAGEM}


É preciso situar as interfaces digitais no domínio da linguagem para entendermos as possibilidades de produção de sentido desses comandos icônicos, textuais, imagéticos, sonoros e hipermidiáticos, que medeiam a relação entre usuários em uma experiência digital de navegação, quando atuam na superfície das dimensões textuais.

A seguir, apresento três perspectivas de compreensão das interfaces digitais: as interfaces digitais como diálogo, como mídia remediada e como um sistema de signos com convenções típicas.

\section{Interfaces digitais como diálogo}

Nos estudos em Interação Humano-Computador, campo interdisciplinar filiado à Ciência da Computação, a ideia de comunicação homem-máquina foi sendo substituída pela de interação entre programadores, engenheiros de software e usuários e, mais recentemente, entre usuários, por meio da mediação tecnológica (NADIN, 1988; Signorini; Calvalcanti, 2010). Nessa perspectiva de interação, Nadin (1988) postula:

[...] não existe comunicação homem-máquina; isso é uma maneira de dizer, uma maneira de antropomorfizar máquinas. Comunicação é a atividade semiótica que aproxima usuário e designer. Uma vez que o usuário aceita uma linguagem, ele vai aplicá-la de acordo com as regras que o designer embutiu na interface, e a comunicação deles, mediada por uma máquina, vai acontecer. (NADIN, 1988, p. 284, tradução minha) ${ }^{1}$

Uma das correntes teóricas que atuaram para essa mudança de perspectivas é a Engenharia Semiótica, que vê o desenvolvimento dos sistemas interativos como um processo de expressar ideias, intenções, valores e ações por meio do software. As interfaces digitais, a partir de suas restrições tecnológicas e suas convenções semióticas, são consideradas:

[...] um artefato de metacomunicação através do qual o designer envia para os usuários uma mensagem expressa através da interface, cujo conteúdo é o modelo conceitual da aplicação. A mensagem do designer tem uma natureza dinâmica e interativa, pois é formada pelo conjunto de signos - palavras, gráficos, figuras, sons, etc. - trocados entre o usuário e sistema durante o processo de interação (LEITE; DE SOUZA, 1999, p. 1).

\footnotetext{
${ }^{1}$ No original: "There is no such thing as man-machine communication; this is a way of speaking, a way of anthropomorphizing machines. Communication is the semiotic activity that brings user and designer together. Once the user accepts a language, he will apply it according to the rules the designer embedded in the interface, and their communication, mediated by a certain machine, will take place."
} 
As pesquisas interdisciplinares do "The Semiotic Engineering Research Group"2 apresentam um avanço não só para o desenvolvimento dos sistemas informáticos, como também para a compreensão das interações digitais em sua complexidade, aproximando os estudos sobre desenvolvimento de sistemas informáticos da perspectiva dos estudos da linguagem.

Estabelecer as condições de produção desse processo interativo é uma contribuição importante da Engenharia Semiótica para o design de interfaces e para o campo da IHC. Mesmo com conceitos e modelos filiados à Teoria da Comunicação, com ajuda da Engenharia Semiótica, a Ciência da Computação passa a colocar em perspectiva o processo interativo que emerge entre designers, programadores, leitores/navegadores e interfaces.

Nessa perspectiva, o designer fala pela interface, e essa, por sua vez, atua como preposto de sua mensagem para o usuário. A voz desse preposto é autorizada pelo designer e restringida pela interface e sua sintaxe, que atuam em sistema de metacomunicação: “[...] comunicação emitida pelo designer ao usuário, via interface, sobre como o sistema deve ou pode ser usado, por que, e com que efeitos" (LEITÃO; SILVEIRA; DE SOUZA, 2013, p. 6).

Essa virada é importante também para o posicionamento das interfaces digitais no campo da Linguística Aplicada e das pesquisas sobre ensino e aprendizagem da leitura, pois situa os agentes em interação e permite que todos se enxerguem, tomem consciência uns dos outros, cada um do seu lugar de atuação.

A noção de polifonia pode ajudar a entender como competem essas vozes na interação digital via interfaces, e como são evocadas de forma híbrida em outros contextos. Para estudar a formação do romance alemão, o filósofo russo toma de empréstimo o nome dado a um estilo de música que se desenvolveu na Idade Média, com raízes populares e que surge como contraponto ao canto monódico da Igreja, o canto gregoriano. No canto polifônico, cujo surgimento é atribuído ao século XII, a "[...] segunda voz passa a rebater nota por nota a melodia do cantochão em movimentos não apenas paralelos, mas variados, contrários, oblíquos" (ROMAN, 1992-1993, p. 208).

\footnotetext{
${ }^{2}$ Coordenado pela professora Clarisse Sieckenius de Souza, titular do departamento de Informática da PUC-Rio. Disponível em: http://www2.serg.inf.puc-rio.br/. Acesso em: 27 out. 2017.
} 
A polifonia no romance de Dostoievski se manifesta, segundo Bakhtin (2006), na diversidade de "vozes controversas", atuando de forma independente em um mesmo enunciado (o espaço do romance), todas representantes de determinado conteúdo e marcadas pelas peculiaridades desse universo.

Assim como fez Bakhtin com o conceito de polifonia, tomando-o como metáfora da música para a literatura, é possível usar a noção de polifonia para entender as vozes em diálogo nas interações mediadas por interfaces e, mais ainda, para entender como esse processo de metacomunicação emerge de forma híbrida como mais uma das vozes em diálogo nos textos multimodais que usam elementos de interfaces digitais em seu enunciado.

Na dimensão discursiva, portanto, é possível defender a configuração polifônica da interação digital, que coloca em negociação as vozes dos designers e programadores e as dos usuários (leitores e navegadores) dos sistemas informáticos. Cada uma delas atuando de forma independente, em um mesmo ambiente: interfaces de softwares ou de plataformas web, por exemplo.

Essa perspectiva ajuda a compreender a "angústia da interface", descrita por Zumpano (2005, p. 104), ou a "[...] incerteza da efetividade da interface e [n]a dificuldade de identificar esse outro, de nomear quem fala comigo".

As interfaces, como manifestações da linguagem hipermídia, trazem em sua forma composicional elementos de vários sistemas semióticos do mundo contemporâneo. São heranças de outras formas culturais, como livros e outros objetos associados à leitura na era do impresso, imagens em movimento do cinema e da televisão e signos de sinalização urbana, criados para facilitar o trânsito das pessoas pelos lugares públicos, como rodoviárias, aeroportos, museus, praças públicas. Todas essas mídias negociam espaço na interface a fim viabilizarem a experiência do usuário. As interfaces como remediações de outras mídias é o tópico discutido a seguir.

\section{Interfaces como mídia remediada}

Ao estudarem relações e permeabilidades entre diferentes meios de comunicação, os historiadores Asa Briggs e Peter Burke (2004) propõem tomar a mídia como “[...] um 
sistema em contínua mudança, no qual elementos diversos desempenham papéis de maior ou menor destaque" (BRIGGS; BURKE, 2004, p. 15). As relações entre mídias são postas na perspectiva de sistemas: uma mídia não pode ser vista a partir de fatos isolados e meios que se sobrepõem aos outros, mas como um sistema em contínua mudança, em que uma rede de elementos e agentes interagem e evoluem:

[...] para estimar as consequências sociais e culturais da nova técnica, é necessário ver a mídia como um todo, avaliar todos os diferentes meios de comunicação como interdependentes, tratando-os qual um pacote, um repertório, um sistema, ou o que os franceses chamam de "regime". (BRIGGS, BURKE, 2004, p. 33).

Lev Manovich (2001) acrescenta complexidade a essa visão sistêmica ao lidar com a noção de "regime", sob o qual operam os signos em ambientes digitas. Cada meio opera segundo um regime, uma organicidade. Manovich concebe as interfaces como sistemas estáveis e organizados a partir de unidades mínimas, que redefinem a condição das imagens contemplativas da era moderna. $\mathrm{O}$ estudioso das novas mídias estabelece quatro pontos importantes no caminho dessa compreensão: a) as interfaces materializam formas como os leitores/navegadores concebem o próprio computador; b) determinam o que esses sujeitos pensam sobre os objetos de mídias acessados via restrições digitais; c) impõem sua própria lógica a outras mídias diferentes; e d) fornecem modelos distintos do mundo.

Os sistemas de mídias estão em constante evolução e se movimentam aproximando-se e contaminando-se mutuamente, por meio de membranas-fronteiras pouco estanques. Os regimes particulares de cada meio operam relações genealógicas e gerenciam um processo que Bolter e Grusin (2000) chamaram de "remidiação". Um processo que não surge, é claro, com as mídias digitais. A remidiação faz parte do regime de qualquer meio, já que esses não surgem e não operam isoladamente e estão sempre se adaptando, reorganizando-se, acomodando-se. Fazem parte da natureza dos meios as relações de "respeito e rivalidade” entre mídias diferentes (BOLTER; GRUSIN, 2000).

Para esses pesquisadores, novos meios precisam "pedir emprestados" objetos, processos, formas de operar, até se estabilizarem, acomodarem-se na paisagem comunicacional. Filiados à ideia foucaultiana de genealogias, Bolter e Grusin acreditam 
que, assim como nas relações de poder, os meios também se filiam por suas relações formais, de poder cultural, de prestígio (BOLTER; GRUSIN, 2000).

Remidiação é a lógica da dupla mediação: quando elementos típicos de certo meio emergem e se articulam em outro. Nossa cultura conceitua cada mídia ou constelação de mídias a partir do modo como essas respondem, reorganizam e competem. Um meio antigo não pode ser totalmente substituído. O que existe são formas diferentes de remidiação, de adaptação, que podem ser mais ou menos reconhecidas pelos usuários.

Bolter e Grusin (2000) defendem que toda mediação é remidiação (a escrita é remidiação da fala, por exemplo). Segundo os autores, todas as mídias que existem funcionam como remidiadoras, e essa remidiação nos fornece meios para interpretar o funcionamento das mídias anteriores.

A ideia de genealogia, tal qual como apresentada pelos pesquisadores, pode passar a impressão de que as filiações são relações construídas linearmente, e acontecem "[...] em um contínuo, quando as mais novas remediam as predecessoras" (BOLTER; GRUSIN, 2000, p. 45). Mas mesmo essa perspectiva linear é questionada e relativizada pelos autores, quando atestam para o rápido desenvolvimento dos meios digitais e a recente rápida resposta dos meios tradicionais. Os antigos meios eletrônicos e impressos estão procurando reafirmar seu status dentro da nossa cultura, assim como as mídias digitais desafiam esse status.

Os impressos também têm tentado acompanhar a evolução provocada pelo avanço das tecnologias digitais. O tempo todo vemos revistas, jornais e livros que "brincam" de se parecer com outros meios, como a televisão e a internet, tanto no estilo de escrita, na temática, quanto na aparência. Revistas reproduzem interfaces de blogs, sites reproduzem páginas de livro (com barulho de virar a página), programas de TV exibem janelas clicáveis na programação, clipes de música e filmes exibem conteúdos de dispositivos digitais. Os exemplos são muitos.

Para além da lógica binária da substituição, concordamos com Ribeiro (2008), quando explica a remidiação: 
[...] tudo isso está interligado, e as mídias, modernas ou tradicionais, se tocam umas às outras, ou seja, não são indiferentes umas em relação à existência das outras e a seus efeitos. Outro ponto é que as mídias nem sempre competem entre si. É comum que comecem até a se "imitar" ou que, para sobreviver, uma mídia mais tradicional se reconfigure para manter entre as opções do leitor/usuário. (RIBEIRO, 2008, p. 23)

A filiação estética e formal entre as interfaces digitais e outras estéticas artísticas modernas ou de vanguarda foi explorada por Braga (2004), que detectou em sua pesquisa relações - mais próximas do que esperava - entre a linguagem hipermídia e o cubismo, o futurismo, o dadaísmo, o construtivismo e certos princípios de design, como os formulados pela escola Bauhaus. Tais semelhanças estão situadas em questões como a não linearidade, a participação do observador/usuário como prioridade, a presença de feedbacks, entre outras.

Essa visão também está em Manovich (2005), quando analisa a qualidade das mídias digitais (ou "novas mídias", para usar a expressão do autor) a partir da dialética tecnológico X cultural.

\footnotetext{
Nas últimas décadas do século XX, a moderna tecnologia da computação e da rede materializou certos projetos-chave da arte moderna desenvolvidos aproximadamente na mesma época. No processo dessa materialização, as tecnologias ultrapassaram a arte. Isto é, não apenas as tecnologias das novas mídias - a programação de computadores, a interface homem-máquina, o hipertexto, a multimídia computadorizada, a formação de redes (com e sem fio) - concretizam ideias por trás dos projetos dos artistas, mas ampliaramnas muito mais do que o imaginado originalmente. (MANOVICH, 2005, p. 49)
}

A linguagem instaurada com as interfaces digitais é resultado dessa hibridação de linguagens predecessoras, como a do design gráfico, do cinema e da TV. Entender a configuração genealógica das interfaces em relação aos outros meios pode ser o caminho para estudar como esse movimento ocorre em direção oposta, quando essa linguagem passa a redefinir produção de sentidos em outros meios, fornecendo subsídios conceituais para significações de sinalização, orientação, feedback, confirmação, exclusão, espera, entre outros.

A "computadorização" dos meios predecessores é um processo semelhante ao que Bakthin chamou de "romancização", ou a influência transformadora do romance sobre todos os demais gêneros (BAKTHIN, 2003, p. 347). 


\section{Interfaces digitais e suas convenções}

Pensar interfaces digitais como um sistema de signos é importante para situarmos as tecnologias digitais e seus objetos "[...] como objetos socio-técnicos por um lado, e como objetos de linguagem, ou objetos semióticos, por outro" (SIGNORINI; CAVALCANTI, 2010, p. 421), buscando a compreensão das interfaces como objeto semiótico de mediação tecnológica.

Seus recursos semióticos sinalizam andamento de processos, indicam caminhos, orientam sobre possibilidades e restrições. Como dispositivo de mediação e conexão entre meios, as interfaces conectam domínios separados, como uma ponte, um ponto de contato. Ao mesmo tempo em que referenciam ao sinalizar, apontar, indicar, restringir, as interfaces digitais se autorreferenciam.

São representações (muitas vezes arbitrárias, outras metafóricas) que dão sentido a outros dados (ou representações, ligadas ao sistema de processamento digital). Interfaces, na qualidade de metaformas, atuam como tradutoras dos processos digitais, extrapolam o domínio da forma, daquilo que envolve o texto. Para serem compreendidas - e até para exercerem sua função sinalizadora - precisam significar em si mesmas.

A interação entre desenvolvedores, usuários e interfaces é organizada por "convenções": recursos semióticos que significam relações de correspondência, subordinação, ordem, sintaxe. O termo "convenção" é usado por Manovich (2001) para identificar o "regime" sob o qual operam sistemas de significação que vão se estabelecendo nos usos e nas remediações e, com isso, influenciam formas diferentes de construir sentido para o mundo, como foi o caso do modelo de rolo de câmera ou é agora das janelas roláveis ou operações de cortar e colar digitais. Para o pesquisador:

[...] à medida que a cultura computadorizada gradualmente espacializa todas as representações e experiências, elas ficam sujeitas à gramática de acesso a dados específica da câmera. Zoom, inclinação, panorâmica e rastreamento - 
agora usamos essas operações para interagir com espaços de dados, modelos, objetos e corpos. (MANOVICH, 2001, p. 80, tradução minha) ${ }^{3}$

As interfaces gráficas de usuário, a partir da década de 1980, passam a redefinir a condição das imagens contemplativas da era moderna. A possibilidade de interação traz a oposição figura-fundo como elemento fundamental para representar a relação entre um fundo passivo, não interativo (como o caso dos padrões desktop), ícones e hiperlinks ativos (como os ícones de documentos e aplicativos que aparecem na área de trabalho). Para Manovich (2005):

[...] o tratamento de imagens de representação das novas mídias representa um mix entre essas duas convenções, muito diferentes. Uma imagem conserva sua função de representação ao mesmo tempo em que é tratada como uma série de hot spots (imagemap). Essa é a convenção-padrão da multimídia interativa, nos jogos de computador e nas páginas da internet. [...] uma convenção de IHC é "sobreposta" (nesse caso, metafórica e literalmente, como um designer coloca hot spots sobre uma imagem existente) a uma convenção de representação. Outra maneira de pensar sobre isso é dizer que uma técnica normalmente usada em controle e administração de dados é misturada com uma técnica de representação ficcional e narração ficcional. (MANOVICH, 2005, p. 34-35).

Tais convenções operam dentro do "regime" digital e atuam como uma sintaxe. Em Novais (2008) defendi um modelo de leitura para as interfaces que previa três domínios: o domínio das unidades (imagens, ícones de interface, botões, janelas, ponteiros, etc.), o domínio sintático (reconhecimento das convenções ligadas a rotinas de navegação, como a hierarquização em janelas, a organização dos dados, etc.) e o domínio semântico (interpretação em um nível mais amplo de convergência, que opera não só a partir da materialidade das interfaces, mas também de conhecimentos sobre a cultura digital).

O domínio sintático estaria ligado a conhecimentos sobre o modo de operar das interfaces digitais ou suas convenções. As convenções de interface não se alteram tanto entre programas de empresas concorrentes. Muitos padrões de interação se mantêm, por já estarem canonizados e consolidados pelos usuários, como identificação dos arquivos e pastas, exibição dos programas a partir de quadros chamados "janelas" ou as "barras de rolagem", localizadas na parte lateral das janelas, que fazem com que as páginas do documento se comportem como os antigos rolos.

\footnotetext{
${ }^{3}$ No original: "As computer culture gradually spatializes all representations and experiences, they are subjected to the camera's particular grammar of data access. Zoom, tilt, pan and track - we now use these operations to interact with data spaces, models, objects, and bodies".
} 
Há ainda os artifícios gráficos para simular ações e instruções dadas ao computador, como a ação de selecionar uma parte do texto ou a ação de pressionar um botão na tela, e mesmo o recurso que indica qual janela está ativa e qual não está. São princípios que se estabilizaram já com as primeiras interfaces gráficas para computadores pessoais e que, ao longo do tempo, vêm se aprimorando e se refinando. $\mathrm{Na}$ imagem a seguir, convenções de interface determinam que o botão "Sim" está acionado - porque está destacado em azul - e que a mensagem de sistema está sobreposta à janela do documento no Bloco de Notas.

Imagem 1 - Recursos semióticos em convenções de interfaces no Windows XP.

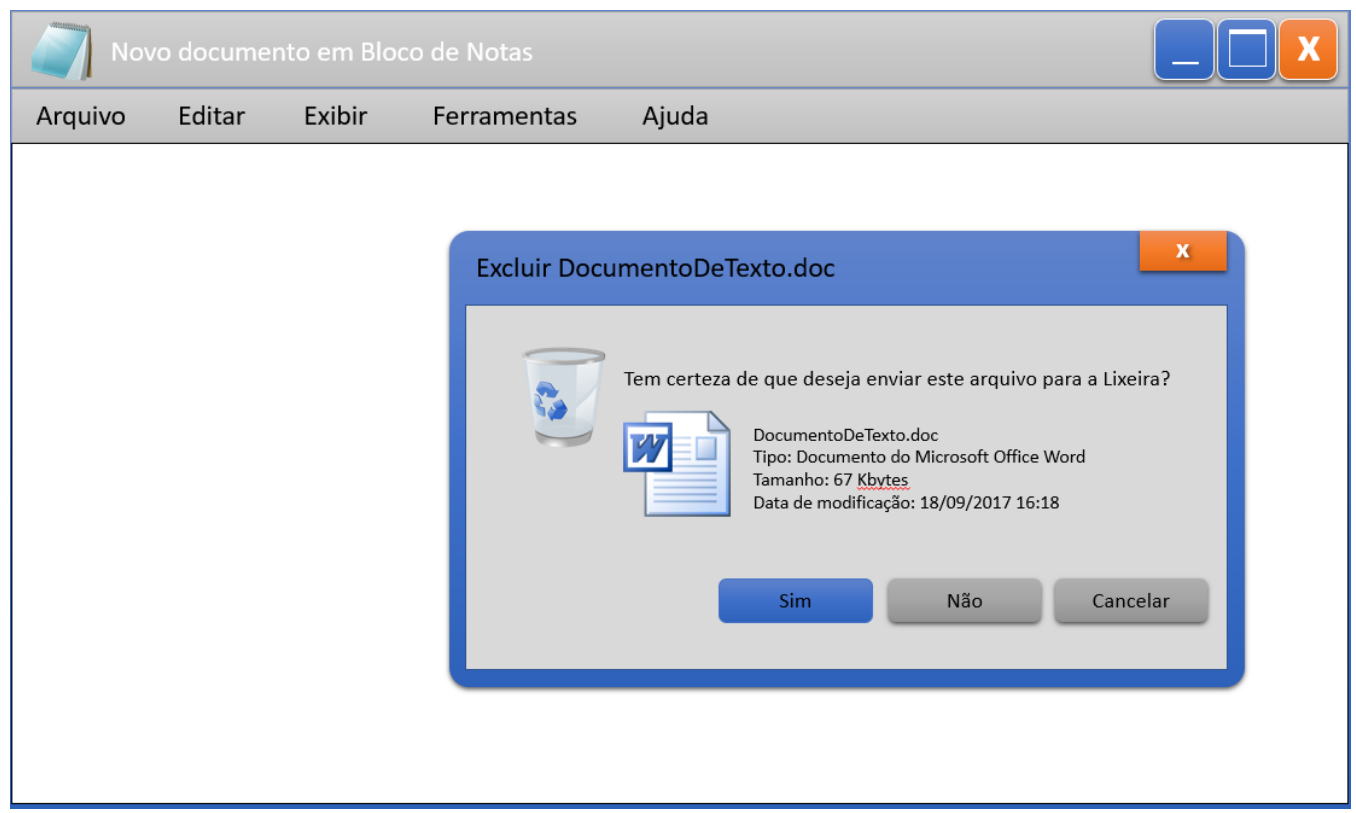

Fonte: elaborado pela autora.

Lévy (1998, p. 57) afirma que todos os elementos das interfaces digitais são significantes. Segundo ele, “[...] mesmo eventuais correspondentes não-icônicos e puramente convencionais, por exemplo, a forma redonda ou quadrada em que se inscrevem as figuras ideográficas, remetem a uma significação a pertinência do objeto designado a esta ou àquela categoria".

Colusso (2014) investigou o papel da Teoria da Metáfora Conceptual para o desenvolvimento de interfaces digitais e delimitou três processos distintos e complementares para a compreensão das interfaces: apresentação, interação e relação entre objetos. Nesse modelo conceitual, os processos são dispostos em forma de 
iceberg: no topo, a apresentação, seguida da interação e das relações entre objetos. A apresentação é a "superfície", que se materializa com recursos semióticos: layouts, cores, quadros, textos, imagens, gráficos, animações. É a parte mais superficial, óbvia e de fácil compreensão. Na camada da interação estão as ações emergentes ativadas via teclado, mouse, consoles de games e telas sensíveis ao toque. Na base do iceberg - que, segundo Colusso, engloba $60 \%$ dos aspectos críticos da interface de usuário - estão as relações entre objetos e suas propriedades. Nessa etapa, “[...] os designers determinam as metáforas apropriadas para casar o modelo mental que o usuário tem do sistema e as tarefas que ele precisa realizar. Esta parte do iceberg está submersa e não é facilmente visível" (COLUSSO et al., 2012, p. 5).

É na base do iceberg, acredito, que são planejadas e construídas as convenções de interface, padrões de relação entre seus elementos, repletos de significação, que nos ajudam a entender melhor as experiências digitais. Em busca de si mesma, "[...] essa nova linguagem busca a criação de hiper-sintaxes capazes de refuncionalizar linguagens que antes só muito canhestramente podiam estar juntas, combinando-as e retecendo-as em uma mesma malha multidimensional" (SANTAELLA, 2001, p. 392).

De acordo com Novais (2008), a construção de sentido na interface não está relacionada apenas à decodificação de unidades isoladas, como ícones, botões, etc., mas sim ao reconhecimento de uma rede complexa e coerente de relações entre esses elementos, a sua função em determinado contexto, a sua disponibilidade dentro daquela situação.

\section{Interfaces digitais: superfícies com objetos acessíveis e manipuláveis}

Para visualizar as dimensões acima atribuídas às interfaces digitais e compreender como atuam as convenções de interface fora das telas, adaptei a proposta de Colusso (2014) para o estudo das metáforas de interfaces. Neste trabalho, serão analisados seis textos, dois deles que exploram os sentidos gerados pelas superfícies onde se organizam os elementos em uma área de trabalho. Superfícies essas que são múltiplas, através das quais é possível mover, arrastar, selecionar o que será enquadrado no campo de visão, o que será eliminado, etc. Outros quatro textos exploram as ações de navegação ligadas à manipulação desses elementos: são as ações de arrastar, navegar por um menu, clicar em um botão. 


\section{Superfícies e objetos}

A compreensão de certas experiências em termos de objetos e superfícies nos permite fazer referência a elas, categorizá-las, agrupá-las, quantificá-las. Nas interfaces digitais, essas relações ontológicas são estabelecidas figurativamente na metáfora do espaçoinformação (JOHNSON, 2001), conjunto de convenções que nos permitem visualizar uma área multidimensional sobre a qual se movimentam os elementos de interface como uma superfície de trabalho. A área de trabalho das interfaces desktop é a superfície mais básica, uma área de contenção que pode ser sobreposta por outras, com iguais propriedades e formas de interação.

Provavelmente, a metáfora da interface do usuário mais conhecida das experiências digitais é a metáfora da "área de trabalho", ou metáfora do escritório, ou ainda a metáfora desktop. Ela está presente nas interfaces gráficas de muitos sistemas operacionais, substituindo aqueles que utilizavam apenas linhas de comando.

Essa metáfora foi criada sob o paradigma da interface "amiga do usuário" ou seja: sistemas mediadores criados para serem fáceis de usar. É uma metáfora conceptual que estrutura a área das telas digitais em termos de ambiente de trabalho em escritório, e dessa forma organiza submetáforas - "arquivos" e "pastas" ou ainda ações como “copiar”, "mover", “apagar”.

Em nossas experiências com o mundo físico, percebemos como superfície o que se apresenta nos limites de nosso campo de visão. Como seres físicos, delimitamos o mundo à nossa volta tendo como referência, por exemplo, a superfície de nossas peles. Projetamos nossa orientação sobre o que está sobre ou sob as superfícies e sobre (ou sob) os objetos que também são delimitados por uma superfície. Assim também os visualizamos como recipientes com um interior e um exterior.

Nas interfaces digitais que funcionam sob a metáfora desktop, a área de trabalho é a superfície mais básica, que suporta as outras superfícies e objetos manipuláveis. Sobre ela estão os ícones, as janelas, as mensagens de sistema, os botões de comando. O ponteiro do mouse é a entidade manipuladora e se apresenta sempre sobreposta a todas as outras. Essa metáfora dominou, até há bem pouco tempo, os projetos e modelos conceituais de interfaces gráficas digitais. 
Mesmo com as novas interfaces abandonando a ideia de "área de trabalho", o sentido de superfície continua metaforizado nos ambientes digitais. As relações de distância, volume e dimensão são comprimidas por recursos semiótico-cognitivos, tais como, perspectiva e gestalt. Superfícies podem ser sobrepostas e, dessa forma, estabelecem uma relação gestáltica de figura e fundo. O que define uma superfície em relação à outra, na dimensionalidade das telas digitais, são recursos semióticos integrados com as convenções de interface.

Quando essa representação é transposta da tela para a dimensão do texto impresso, o sentido de manipulação é projetado, mesmo que as possibilidades de navegação típicas do digital não existam mais. No texto a seguir, uma propagada de agência de viagens feita para circular em meio impresso (revistas e jornais), explora a ideia da área de trabalho, suas superfícies e objetos.

Imagem 2 - Propaganda impressa com área de trabalho.

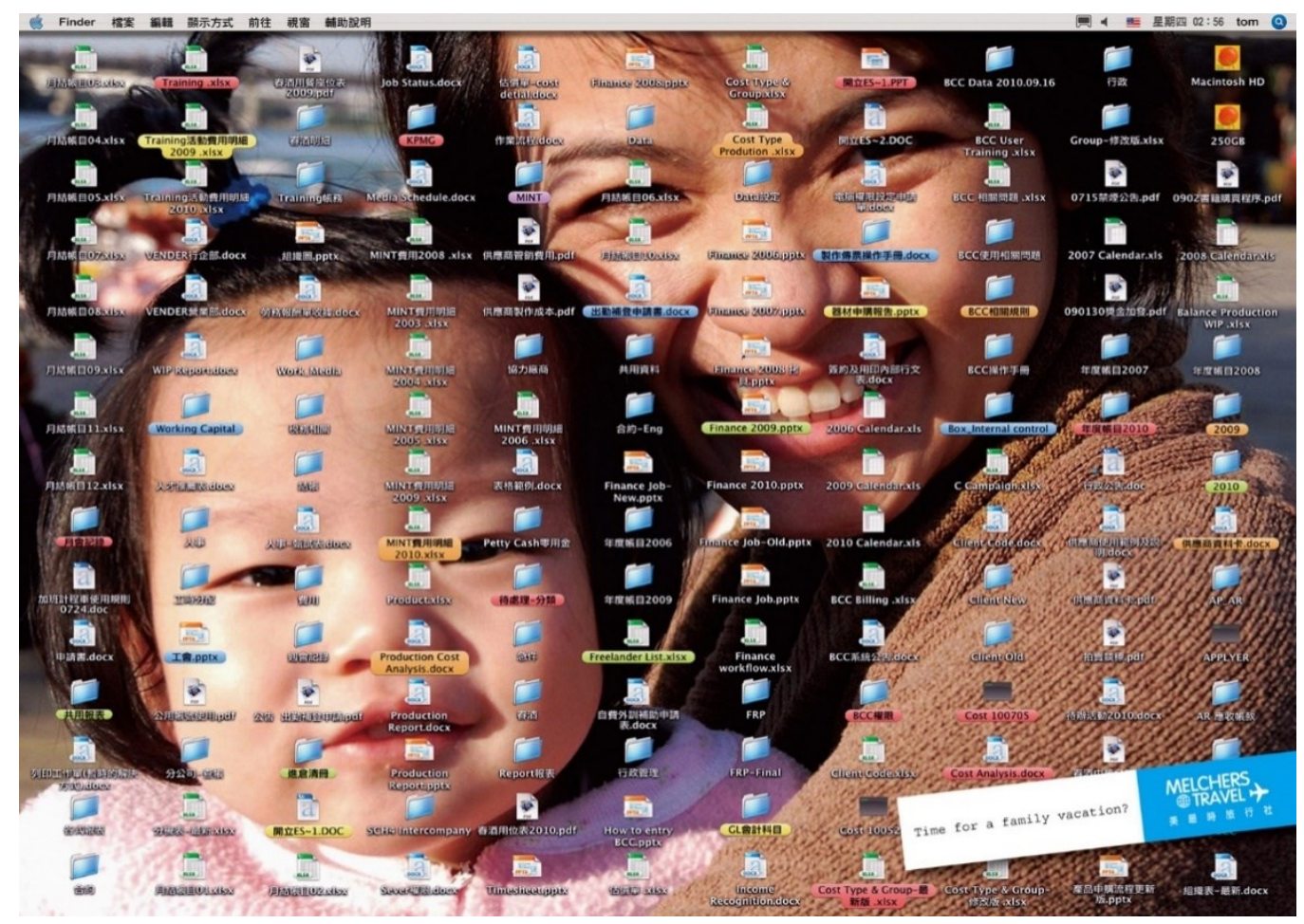

Fonte: (MelchersTravelAgency..., 2010).

Nesse texto, a fotografia de duas personagens femininas, uma mulher adulta e uma criança, está sobreposta por ícones e por uma barra de tarefas na parte superior. Uma etiqueta com o slogan “Time for a family vacation?” (Tempo para férias em família?) e 
o logotipo de uma agência de viagens sobrepõem os outros elementos do texto, no canto inferior direito.

Em uma leitura possível, a imagem da tela de um computador, com uma área de trabalho repleta de ícones, sugere que o dono desse equipamento está sobrecarregado de trabalho e que a solução para essa sobrecarga são férias em família. Ícones de computador podem representar documentos, imagens, planilhas, programas, pastas com mais documentos, entre outros elementos. Cada ícone representa, nesse caso, uma atividade ligada a um tipo de trabalho a ser executado. Trabalho este que, segundo a imagem, está sobrepondo a - e, portanto, é hierarquicamente mais importante que - a família.

O reconhecimento do gênero textual aciona o domínio da publicidade, seus padrões e estereótipos de "família feliz". Tanto a imagem agradável representada na fotografia de duas pessoas sorrindo em close, quanto o slogan da propaganda posicionado no canto inferior direito do texto são da ordem das relações familiares, dos afetos, da subjetividade.

O domínio familiar comporta todas as outras superfícies e objetos porque é representado pelo elemento que está sob, abaixo das outras superfícies e objetos. O domínio das experiências digitais traz ao leitor a experiência de pensar em possibilidades de manipulação desses objetos sobrepostos. Se "muito trabalho sobrepõe a família", é possível "deletar" esse trabalho, "agrupá-lo", "limpar a área de trabalho" e sair de férias.

A propaganda propõe que é ruim/negativo sobrepor o trabalho à família quando coloca a fotografia de uma família feliz como plano de fundo da área de trabalho do computador, lotada de ícones. Diante dessa cena, fica mais fácil aceitar o argumento publicitário de que, quando essa situação acontece, é preciso conseguir "tempo para viajar de férias com a família".

Outra convenção de interface que depende da noção de superfície e suas sobreposições é o menu. Um menu é uma lista de opções para acesso a funcionalidades de um sistema de digital. Essa convenção é responsável por organizar hierarquicamente os controles e recursos de cada interface. As ferramentas de um menu digital são elencadas por 
comandos verbais que se agrupam por similaridade (semântica, funcional, entre outros). É o recurso que fez os usuários não mais precisarem memorizar linhas de comandos.

Os menus restringem a navegação a um movimento direcionado pelos designers de programação. A arquitetura da informação e os recursos semióticos correspondentes ditam ao usuário para onde ele deve mover o ponteiro ou passar de um item de menu a outro até chegar ao comando desejado. Opções de menu podem estar disponíveis ou não, e essa informação é dada através de recursos semióticos. Uma opção desativada geralmente recebe uma cor diferente (mais clara), uma opção acionada recebe uma cor mais vibrante. Nos ambientes digitais, enquanto passamos o mouse pelas opções de um menu, elas vão sendo destacadas para indicar que estão ativas.

A arquitetura da informação, no caso dos menus, permite a navegação em vários níveis. Uma opção pode ser expandida em outras (submenus) e, nesse caso, essa funcionalidade é sinalizada com uma seta. Os itens de menu representam opções individuais, organizadas por recursos semióticos como linhas e outras guias. Graças a esses recursos semióticos, o funcionamento de um menu digital pode fazer parte da produção de sentido de um texto bidimensional. A linearidade dos textos de modalidade verbal é substituída por relações espaciais típicas da navegação digital, como no exemplo a seguir.

Imagem 3 - Post do Twitter com menu.
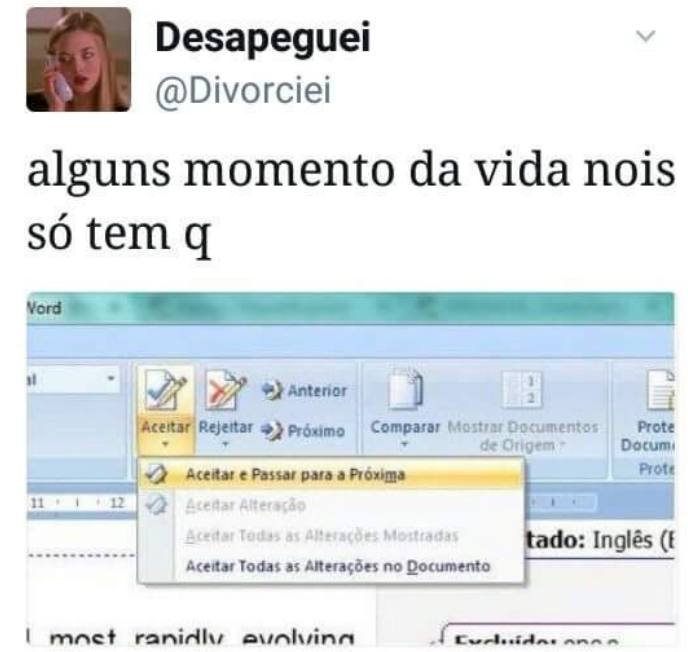

Fonte: printscreen do perfil do Twitter@divorciei, 2017. 
Esse exemplo exibe um post da rede social Twitter chamado@Divorciei, cujo "apelido" atual é "Desapeguei” (informações recuperadas por convenções de interface dessa rede social). O conteúdo do post integra um texto verbal com uma oração sem complemento ("alguns momento da vida nóis tem q") e um recorte da interface do editor de textos. A convenção de interface que altera a aparência das opções de menu quando estão acionadas permite inferir que o botão "Aceitar" foi pressionado e, como consequência, foi aberto um menu cuja opção habilitada é "Aceitar e passar para a próxima".

Para que o leitor recupere o sentido pretendido para esse texto, é preciso que ele recupere todas essas relações formais que se estabelecem entre as convenções da rede social Twitter, das convenções de escrita de um texto verbal e das convenções da interface do editor de textos. Como resultado dessa integração, é possível extrair desse texto uma proposição parecida com "Em alguns momentos é preciso desapegar, aceitar e passar para a próxima".

O elemento “@divorciei”, convenção de interface que identifica nomes de perfis no Twitter, integrado ao termo "Desapeguei" auxiliam a produção de inferências do domínio dos relacionamentos amorosos, separações e divórcios. Em escala humana de compreensão, as convenções de escrita e as convenções de interface atuam juntas na produção de sentidos e permitem inferir que o texto trata de uma situação em que um relacionamento amoroso não foi bem-sucedido, e que o autor expressa o desejo de seguir em frente, procurando novas possibilidades.

As relações de superfície das convenções de interface digitais que governam os padrões de inferência desse texto, que integra a superficialidade digital, multidimensional com os menus e suas superfícies clicáveis, à dimensionalidade da escrita verbal e suas convenções.

\section{Movimento, manipulação e acesso}

O sentido cinestésico é acionado nas interfaces com o uso do mouse, como quando arrastamos arquivos de uma pasta a outra. O conjunto de sensações que nos permite a percepção de movimentos é simulado por meio de recursos semióticos que acionam sentidos de força e movimento. Tais realidades se constroem em propriedades cinéticas 
proprioceptivas, na sensibilidade de reconhecimento de superfícies em relação ao mundo e por meio de nossa consciência de movimento em relação a essas sensibilidades.

Convenções de interface acionam nosso sentido cinestésico e exploram sentidos relações de manipulação e acesso que se estabelecem via mouse ou teclado. $O$ engajamento do mundo por meio das interfaces digitais se dá a partir da nossa relação com superfícies e objetos, em que ações físicas são simuladas (arrastar objetos, sobrepor superfícies, manipular menus, pressionar botões).

As convenções de interfaces digitais nos proporcionam a sensação de que estamos, por exemplo, movendo objetos de lugar para regular nosso campo de visão ou pressionando um botão para que uma ação seja realizada. Ações como clicar, arrastar, clicar duas vezes e apontar, que só existem devido à nossa capacidade imaginativa e integrativa, não pertencem nem às ações de natureza física, nem às operações possíveis de um dispositivo digital.

Analiso a seguir textos que exploram essa poderosa rede de produção de sentidos ao materializarem botões de comando, ponteiros do mouse, menus navegáveis e objetos manipuláveis (“arrastáveis”).

\section{Pressionar um botão}

As interfaces, como mídia remediada, reposicionam, genealogicamente, elementos de outros sistemas de interação, como as interfaces homem-máquina. Um botão de interface digital tem filiação nos painéis de controle das máquinas industriais. Os botões físicos são elementos importantes da interação homem-máquina desde a era industrial, quando pressionar um botão era ainda uma ação física realizada sobre a superfície mais saliente de uma máquina. Essa ação gerava uma resposta da máquina, geralmente um movimento automático.

Em nossas experiências digitais, assim como nas interfaces homem-máquina, pressionamos botões para que ações aconteçam dentro dos sistemas e ambientes digitais. Um botão de comando simula propriedades físicas de um botão das interações homem-máquina (maior ou menor saliência em relação a outras superfícies, cores e 
formas diferentes). Tais propriedades geram uma demanda, uma força de atração em relação ao ponteiro do mouse, e deles demandam determinada resposta. De acordo com os padrões definidos por Talmy (1987), nos estudos do Design de Interação, o ponteiro do mouse atua, em relação aos botões, menus, janelas e outras superfícies clicáveis, como um atrator, uma entidade que é compelida por uma força externa e, nessa condição, impõe a necessidade de resposta. A atração exercida por um botão de interface também pode ser dada por um movimento ou "aceno", que é uma mudança de estado que acontece quando o ponteiro do mouse passa por sua superfície. Essa resposta gera uma proposição semelhante a "eu posso fazer isso acontecer" ou "eu devo fazer isso acontecer". Os botões de comando acionam essa mesma dimensão quando oferecem possibilidades de acesso a uma "resposta". Mas, ao mesmo tempo em que oferecem, restringem, já que geralmente as opções fornecidas são reduzidas a respostas binárias: Sim/Não, OK/Cancelar, Salvar/Cancelar, Confirmar/Cancelar.

A seguir, analiso dois textos que usam botões de comando em suas composições multimodais. Ambos são compostos como reproduções de mensagens de sistema que contêm botões como opções de resposta para determinada situação. Tais convenções parecem atuar como restrições de sentido, já que cada botão aciona padrões de inferência específicos sobre possíveis consequências da ação de clicar.

Imagem 4 - Remix com botões de comando em mensagem de sistema.

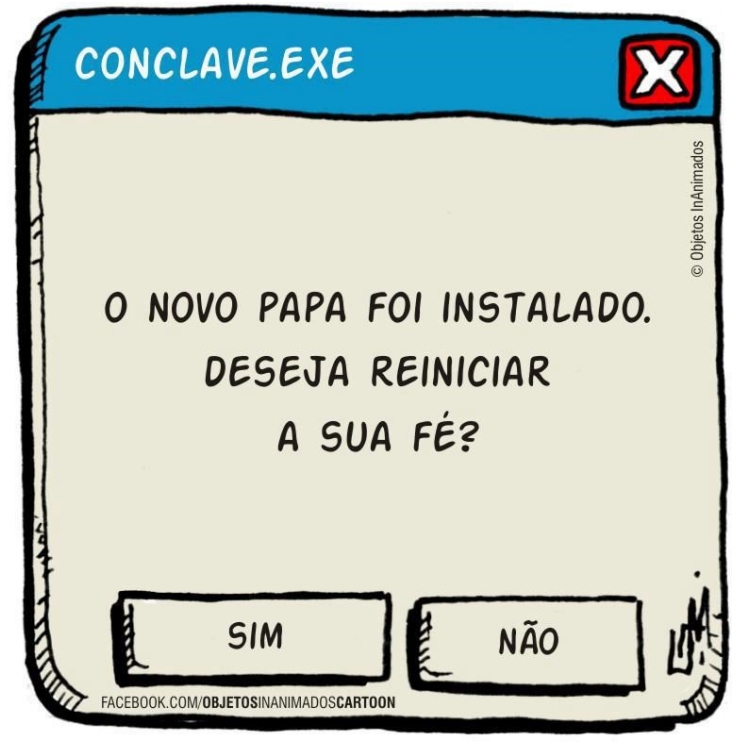

Fonte: Objetos inanimados (2013). 
Esse primeiro texto se apropria dos elementos de uma mensagem de sistema para organizar suas informações e orientar a produção de sentidos. Da barra de títulos, obtemos a informação de que a mensagem está relacionada ao arquivo executável "conclave.exe" (“exe" é a convenção de interface que denomina arquivos executáveis, ou arquivos que, ao serem acionados, executam uma série de comandos de uma só vez).

O nome do arquivo relaciona uma cerimônia católica (Conclave - escolha de um novo Papa) às propriedades de um arquivo executável. O texto verbal contido na mensagem sistema informa avisa o estágio do processo em questão - "o novo Papa foi instalado" e apresenta uma necessidade de resposta - "Deseja reinstalar a sua fé?". Os botões de comando cujos conteúdos são "Sim" e "Não" determinam possibilidades de réplica.

Se aceito as relações entre os elementos do texto e os conteúdos que ele sugere, chego ao sentido emergente de que houve um Conclave e que um novo Papa foi definido. Diante dessa nova situação, há a possibilidade, ou não, de se renovar a fé. Essa é uma possível leitura do texto, dados os conteúdos da mensagem de sistema e dos botões de comando. Os dois botões disponíveis se apresentam como superfícies clicáveis. Como não há destaque para um deles, ou nenhum recurso semiótico que indique que um desses botões está indisponível ou pré-acionado, podemos dizer que esse é um texto que não induz o leitor a uma "decisão".

No texto a seguir, a indução já acontece, porque o leitor é atraído por convenções de interface que acrescentam informações sobre o status dos botões. Com os botões "iluminados" ou sobrepostos pelo ponteiro do mouse, essas convenções atuam como estratégias argumentativo/persuasivas, já que reforçam um dos cenários possíveis, gerados pelo uso de botões. 
Imagem 5 - Cartaz de protesto com mensagem e botões de comando.

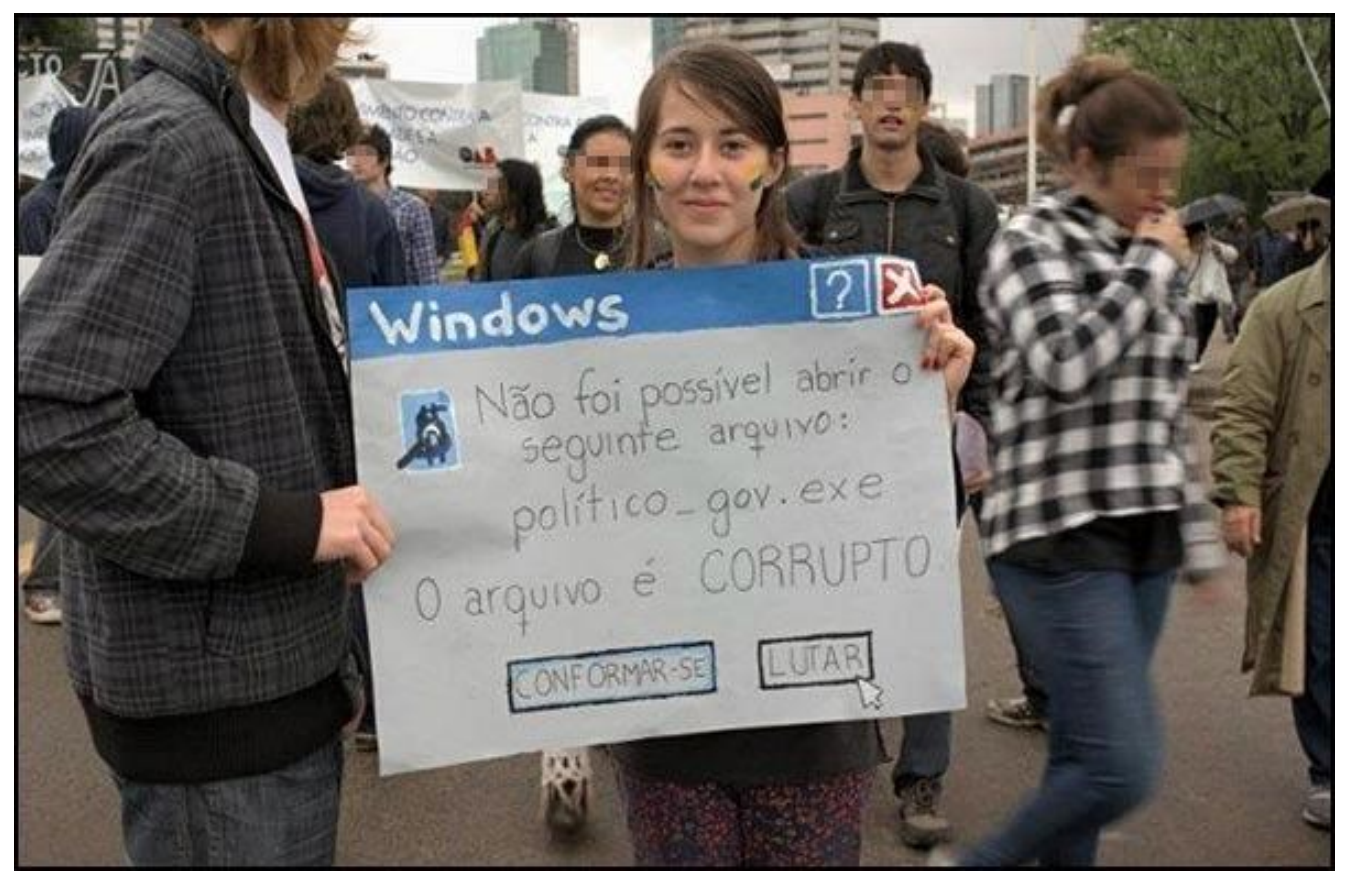

Fonte: Passos (2014).

Este cartaz de protesto simula uma mensagem do sistema Windows. Segundo informações do conteúdo da mensagem, o arquivo executável "político-gov.exe" não pôde ser aberto porque é corrupto. Os botões de comando, cujos conteúdos são "Conformar-se" e "Lutar", fornecem duas opções de ações emergentes. O ponteiro do mouse sobre o botão "Lutar" atrai e induz o leitor para uma das duas opções disponíveis no texto.

Ao comparar políticos a arquivos executáveis, o texto sugere que políticos podem ser acionados para realizar tarefas automatizadas, e que o cidadão não tem responsabilidade sobre elas. É como se o político fosse uma máquina, projetada por um programador, e pudesse ser acionada para realizar uma série de atividades. Como o texto não define quem criou o arquivo executável/político e nem como se daria o "acionamento" desse sujeito/arquivo/político executável, as atribuições convencionalmente atribuídas aos políticos, como a criação de leis e a representação popular, parecem assujeitadas e alijadas do processo de representação política.

A expressão "O arquivo é corrupto" estabelece relações causais entre elementos dos domínios digital e político. Um arquivo/político corrompido/corrupto é a causa do 
problema com o arquivo "político-gov.exe". A qualidade de "corrupto" é um atributo dado a um arquivo executável e, por isso, ele não pode funcionar como deveria. Em termos de sentidos emergentes, o texto parece sugerir que um político corrupto não pode governar ou não "funciona" como deveria.

Essa mensagem de sistema apresenta em sua superfície quatro áreas clicáveis, acionadoras de inferências sobre possíveis resoluções para o problema do político corrupto. O botão Fechar (X) dá a possibilidade de ignorar o processo e interrompê-lo. Nesse caso, um sentido possível para a "resolução" do "problema" detectado pela mensagem seria próximo da resignação ou da alienação. Como se o leitor não quisesse decidir sobre aquela questão e simplesmente ignorá-la. O botão Ajuda (?) aciona outro esquema do domínio das práticas digitais, que empresta para o texto a possibilidade de um cenário em que alguma orientação externa sobre o processo pode ser dada se esse botão for acionado. Nesse cenário, várias possibilidades de leitura são possíveis. Ao acionar o botão "Ajuda", o leitor poderia ter acesso, por exemplo, a um manual cujo texto é extenso, muito técnico e pouco acessível, como acontece na maioria dos sistemas digitais.

Os botões "Conformar-se" e "Lutar" são áreas clicáveis que estão em destaque na mensagem e acionam mais dois outros cenários como possibilidades de produção de sentido. Em um primeiro cenário, o botão "Conformar-se" teria efeitos semelhantes ao botão de "Fechar": nenhuma ação seria realizada e o usuário optaria por aceitar a situação política como está. A diferença aqui estaria no sentido de "ignorar", dado pela função do botão "Fechar" e a declarada resignação materializada pela opção do nome do botão "Conformar-se". No segundo cenário, o botão cujo conteúdo é o verbo "Lutar" se apropria dos sentidos ligados a esse verbo e ao processo descrito na mensagem para explorar a ideia de que uma possibilidade de resposta para o problema do político corrupto é a "luta". O uso desse verbo no botão de comando indica que a ação de lutar seria uma possibilidade de resposta para a corrupção entre os políticos. Dado o cenário político em que esse texto foi produzido (jornadas de junho de 2013 no Brasil), os sentidos de "lutar" e suas consequências tomam proporções exponencialmente complexas. 
Entre as duas opções disponíveis, o ponteiro do mouse posicionado sobre o botão "Lutar" exerce sobre ele a força de atração e, dessa forma, coloca essa opção como mais provável/aceitável dentre as disponíveis. Nesse caso, este recurso semiótico multimodal exerce o papel de um operador argumentativo. A atração exercida pelo ponteiro do mouse sobreposto ao botão funciona como "aceno", que direciona a produção de sentidos para determinado cenário desenhado pelo autor do texto. Se nas interfaces digitais os botões e áreas clicáveis geram proposições semelhantes a "eu posso fazer isso acontecer" ou "eu devo fazer isso acontecer", aqui, essa proposição assume um sentido bastante específico, ligado a uma atitude cidadã diante de um problema político.

A seguir, analiso outra qualidade de manipulação de objetos metaforizada pelas interfaces digitais: a ação de arrastar.

\section{Arrastar}

Nesta peça publicitária para revistas impressas, a produção de sentidos está ligada ao sentido de "arrastar", convenção de interface que sugere que objetos podem ser movimentados na área de trabalho com o uso do ponteiro do mouse. 
Imagem 6 - Publicidade impressa com metáfora digital ARRASTAR.

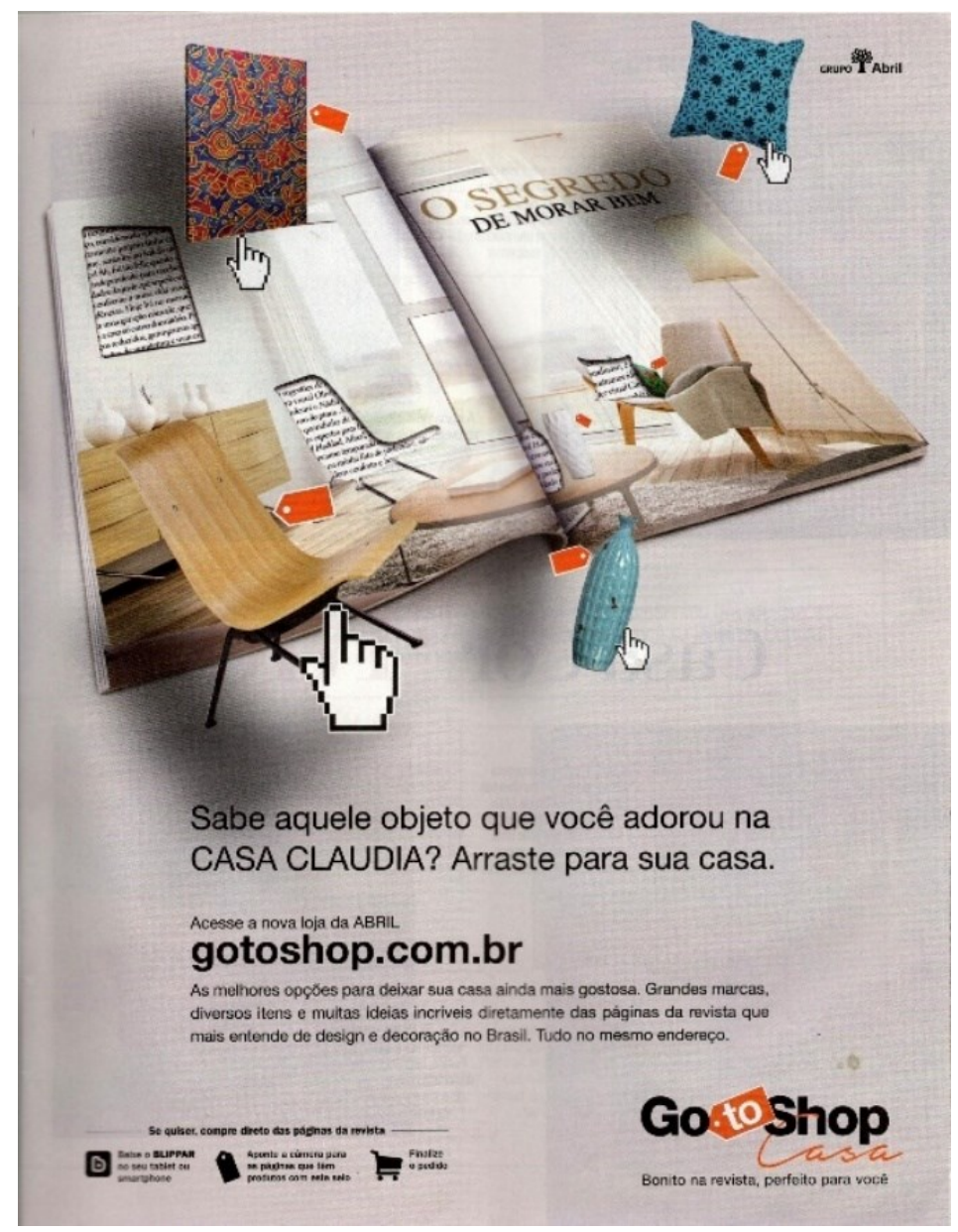

Fonte: Veja (2016).

Com o recurso da metalinguagem, a imagem de uma revista é materializada nas páginas de uma revista real. Os recursos semióticos utilizados conectam a superfície dessa página representada à superfície da revista física, o que faz com que entre os conteúdos da página da revista física estejam o conteúdo de uma página representada.

Objetos de decoração saltam da página representada para a página física, que representa o conteúdo de uma área residencial interna, com móveis e objetos de decoração. A página física da revista impressa contém a imagem da revista aberta, o título da peça publicitária, um link de acesso para o site de vendas e algumas imagens, além do logotipo que identifica o site de vendas.

Elementos recortados, sobreposição e sombras posicionam os objetos de decoração fora da superfície da página representada. Contornos de formas correspondentes aos móveis 
à venda são preenchidos por blocos de textos verbais, o que sugere que a causa da ação de arrastar são os "buracos" nas páginas da revista. O trecho "Arraste para a sua casa", contido no título da peça publicitária, liga os sentidos de "arrastar" das convenções de interface ao domínio das compras on-line.

\section{Navegar por um menu digital}

Outra convenção de interface ligada ao sentido de manipulação e acesso é, como vimos, a representação dos menus em uso, como no texto a seguir, que exibe um Menu de Contexto sobreposto a uma fotografia.

Imagem 7 - Publicidade com menu de contexto em uso.

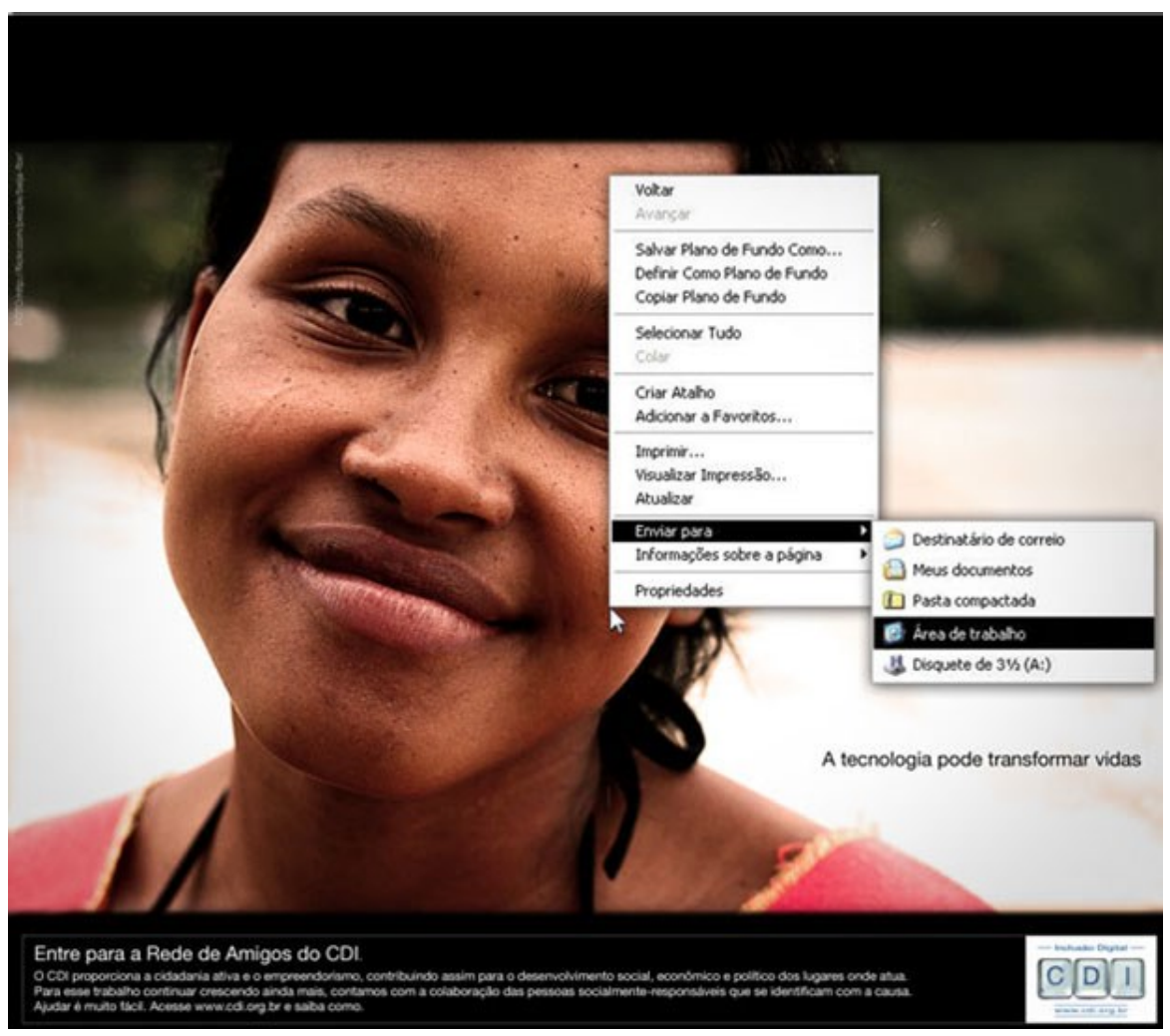

Fonte: (Alunos da UFF..., 2007).

Nesta peça publicitária, feita pra revista impressa, um slogan logo abaixo do menu de contexto sugere intencionalidade: "A tecnologia pode salvar vidas". No rodapé, outro trecho verbal apresenta um convite: "Entre para a Rede de Amigos do CDI". No canto inferior direito, um logotipo determina o sentido da sigla CDI: Comitê para Democratização da Informática. Sobre o logotipo, a expressão "Inclusão Digital” dá 
pistas sobre o objetivo dessa organização. O texto em menos destaque ajuda a complementar a produção de sentido:

ENTRE PARA A REDE DE AMIGOS CDI. O CDI proporciona a cidadania e ativa o empreendedorismo, contribuindo assim para o desenvolvimento social, econômico e político dos lugares onde atua. Para esse trabalho continuar crescendo ainda mais, contamos com a colaboração de pessoas socialmente responsáveis que se identificam com a causa. Ajudar é muito fácil. Acesse www.cdi.org.br e sabia como.

As relações de sentido que o menu de contexto estabelece com o restante dos elementos do texto são estabelecidas por convenções de interface. As opções mais escuras dos menus são as entradas selecionadas e, portanto, as que exercem maior atração. $O$ sentido proposicional emergente desse menu de contexto é dado pelo conteúdo dessas entradas em destaque: "Enviar para a área de trabalho".

Outra convenção de interface que precisa ser recuperada na produção de sentidos desse texto é a de que um menu de contexto é acionado quando clicamos com o botão direito do mouse sobre um objeto na tela. Neste caso, o "objeto" é a fotografia, a imagem feminina em destaque na foto. É possível recuperar esta informação porque o menu de contexto está sobreposto à fotografia.

De posse dessas informações disponíveis na materialidade do texto, é possível recuperar os sentidos pretendidos nessa peça publicitária. O objetivo dessa organização parece ser associado à inclusão digital, nos termos de promover "cidadania" e ativar o "empreendedorismo" para contribuir "para o desenvolvimento social, econômico e político dos lugares onde atua". O sentido de "enviar para a área de trabalho", gerado pelo menu de contexto, reforça os objetivos da entidade.

Das projeções multimodais estruturadas nessas relações emerge o sentido de que, apoiando a ONG Comitê para Democratização da Informática, é possível ajudar pessoas a se apropriar da tecnologia digital e, com isso, a estarem mais aptas para uma vaga no mercado de trabalho. A convenção de interface menu, cujas propriedades são comprimidas na integração conceptual com outros modos semióticos, acolhe e comprime sentidos originados de nossas experiências sobre capacitação profissional, inclusão digital, emprego, melhoria da qualidade de vida. 
A "sensação de interface" é instanciada nos textos pelos movimentos do ponteiro do mouse, pela ação metaforizada de pressionar botões e pela manipulação de menus. Essas convenções projetam em textos bidimensionais movimentos e sensações impossíveis de serem realizados em outros meios. A convenção de interface que define as opções ativas em um menu de contexto pode gerar conteúdo proposicional e compor a produção de sentidos em textos multimodais.

\section{Considerações finais}

A distinção e as assimetrias apontadas por Ribeiro (2008) entre ler e navegar apresentam-se cada vez mais relevantes e necessárias para compreendermos o que se espera hoje de um leitor. Para ler o impresso, além das habilidades de navegação que as convenções deste meio exigem, precisamos recorrer também a habilidades de navegação dos ambientes digitais.

As convenções de interface, quando transpostas da ordem da navegação para a ordem da leitura, demandam do leitor a recuperar sentidos produzidos originalmente nas ações de navegação digital.

Os textos apresentados aqui são representativos desse movimento das mídias que diminui as fronteiras entre o que convencionalmente esperamos encontrar nos meios impressos e digitais. Ao usarem as convenções de interfaces digitais, deslocam esses recursos semióticos de seu habitat natural e, como consequência, exigem deslocamentos importantes em nossos processos de produção de sentidos.

As categorias de Colusso (2014) para compreender as dimensões da figuratividade nas interfaces digitais nos permitem uma compreensão das diferentes habilidades de navegação necessárias para que os textos desta pesquisa sejam compreendidos pelos leitores.

A percepção de superfícies e objetos estabelece relações de prioridade de leitura, de hierarquização das informações no texto. Convenções de escrita são sobrepostas por convenções de interface, por meio das quais os sentidos são estruturados. Um menu de interface digital, quando presente em um texto, pode gerar, com a combinação de suas 
opções destacadas, uma proposição verbal que faz parte do processo de produção de sentidos do texto.

Convenções de interface acionam nosso sentido cinestésico quando movimentos físicos correspondem a movimentos de objetos e superfícies nas telas. Em termos digitais, relações de força e movimento são estabelecidas por ações de manipulação e acesso. $\mathrm{Na}$ dimensão textual, os movimentos da tela não são reproduzidos, mas o seu sentido está lá, e é recuperado por meio dos recursos semióticos que materializam as convenções de interface: a posição do ponteiro do mouse sobre um botão, a cor realçada do botão ou opção de menu, as janelas sobrepostas.

As relações de força e de movimento estabelecidas nas interfaces digitais, quando transpostas para os textos, atuam como acionadoras de cenários possíveis. Com as convenções de interface que demandam uma resposta do usuário (botões, por exemplo), os textos demandam do leitor um engajamento específico, determinado pelas possibilidades e restrições das interfaces digitais. Botões em destaque ou sobrepostos pelo ponteiro do mouse funcionam como operadores argumentativos, pois reforçam seu poder de atração. Esses enunciados estabelecem um pacto comunicativo que demanda do leitor uma necessidade de resposta. Essa demanda é modalizada por convenções de interface.

Se ler e navegar são ações distintas e habilidades assimétricas, para ler textos que usam convenções de interfaces digitais, essas habilidades precisam funcionar cada vez mais conectadas.

\section{REFERÊNCIAS}

BAKTHIN, Mikhail. Estética da criação verbal. Trad. Paulo Bezerra. 4 ed. São Paulo: Martins Fontes, 2003.

BOLTER, Jay D.; GRUSIN, Richard. Remediation. Understanding new media. USA: MIT Press, 2000. 
BOOMEN, Marianne van der. Transcodingthe digital. Howmetaphorsmatter in new media. Amsterdan, Instituteof Network Cultures, 2014. Disponível em:

https://goo.gl/at1ffA. Acesso em: 17 mai. 2017.

BRAGA, Alexandre Santaella. Design de Interface: as origens do design e sua influência na produção da hipermídia. 2004. 135 f. Dissertação (Mestrado em Comunicação e Semiótica) - Pontifícia Universidade Católica de São Paulo, São Paulo, 2004.

BRIGGS, Asa; BURKE, Peter. Uma história social da mídia: de Gutemberg à Internet. Trad. Maria Carmelita Pádua Dias. Rio de Janeiro: Jorge Zahar, 2004.

COLUSSO, Lucas Franco; PEREIRA, Alice Theresinha; GONÇALVES, Marilia Matos. Metáforas de interface. In: CONGRESSO BRASILEIRO DE PESQUISA E DESENVOLVIMENTO EM DESIGN, 10., 2012, São Luís. Anais... São Luís: UFMA. Disponível em: https://goo.gl/PMD2LA. Acesso em: 19 dez. 2016.

COLUSSO, Lucas Franco. Metáforas conceituais para design de hipermídias. 2014. 195f. Dissertação (Mestrado em Design) - Centro de Comunicação e Expressão, Universidade Federal de Santa Catarina, Florianópolis, 2014.

FERREIRO, Emilia. O ato de ler evolui. Revista Nova Escola, 01 jun. 2010. Disponível em: https://novaescola.org.br/conteudo/940/entrevista-com-emilia-ferreiro. Acesso em: 15 out. 2019.

JOHNSON, Steven. Cultura da Interface: como o computador transforma nossa maneira de criar e comunicar. Trad. Maria Luísa X. de A. Borges. Rio de Janeiro: Jorge Zahar, 2001.

LEITE, Jair; DE SOUZA, Clarisse. Uma linguagem de especificação para a engenharia semiótica de interfaces de usuário. In: WORKSHOP SOBRE FATORES HUMANOS EM SISTEMAS COMPUTACIONAIS, 2., 1999, Campinas, SP. Proceedings...

Campinas, São Paulo, 1999. Disponível em: https://goo.gl/KBoqaH. Acesso em: 22 jan. 2017.

LEITÃO, C.F., SILVEIRA, M. S., DE SOUZA, C. S. Uma Introdução à Engenharia Semiótica: Conceitos e Métodos. In: SIMPÓSIO BRASILEIRO SOBRE FATORES HUMANOS EM SISTEMAS COMPUTACIONAIS, 12., 2013, Manaus. Anais... Manaus, Amazonas, 2013. Disponível em: https://goo.gl/rnGyKu. Acesso em: 22 jan. 2017.

LÉVY, Pierre. Tecnologias da Inteligência. O futuro do pensamento na era da informática. Trad. Carlos Irineu Costa. Rio de Janeiro, Ed. 34, 1993. (Coleção TRANS). 
LÉVY, Pierre. A ideografia dinâmica. Rumo a uma imaginação artificial? Trad. Marcos Marciolino e Saulo Krieger. São Paulo: Loyola, 1998.

MANOVICH, Lev. The languageof new media. The MIT Press. Cambridge, Massachussetts. 2001.

MANOVICH, Lev. Novas mídias como tecnologia e ideia: dez definições. In: LEÃO, Lucia (org.). O chip e o caleidoscópio: reflexões sobre as novas mídias. São Paulo: Editora SENAC, 2005. p. 24-50.

NADIN, Mihai. Interface design: a semioticparadigm. Semiotica, Amsterdam, v. 69, n. 3-4, p. 269-302, 1988.

NOVAIS. Ana Elisa. Compreendendo a gramática das interfaces. 2008. 227f.

Dissertação (Mestrado em Estudos Linguísticos) - Faculdade de Letras, Universidade Federal de Minas Gerais, Belo Horizonte, 2008.

RIBEIRO, Ana Elisa. Navegar lendo, ler navegando. Aspectos do letramento digital e da leitura de jornais. 2008. 243f. Tese. (Doutorado em Estudos Linguísticos). Faculdade de Letras, Universidade Federal de Minas Gerais, Belo Horizonte, 2008.

ROMAN, Arthur Roberto. O conceito de polifonia em Bakhtin - o trajeto polifônico de uma metáfora. Letras, Curitiba, n. 41-42, p. 195-205, 1992-93.

SANTAELLA, Lucia. Navegar no ciberespaço. O perfil cognitivo do leitor imersivo. São Paulo: Paulus, 2004.

SIGNORINI, Inês; CAVALCANTI, Marilda C. Língua, linguagem e mediação tecnológica. Trabalhos em Linguística Aplicada, Campinas, SP, v. 49, n. 2, p. 419-440, jul./dez. 2010.

ZUMPANO, Antônio. A angústia da interface. In: COSCARELLI, Carla; RIBEIRO, Ana Elisa. Letramento digital: aspectos sociais e possibilidades pedagógicas. 3 ed. Belo Horizonte: Ceale: Autêntica, 2011. p. 99-104.

\section{NOTAS DE AUTORIA}

Ana Elisa Novais (anaelisanovais@gmail.com) possui graduação em Letras pela Universidade Federal de Ouro Preto (2002), mestrado em Estudos Lingüísticos pela Universidade Federal de Minas Gerais (2008) e doutorado em Programa de Pós-Graduação em Estudos Lingüísticos pela Universidade Federal de Minas Gerais (2018). Atualmente é professora de educação técnica e tecnológica do Instituto Federal Minas Gerais. Tem experiência na área de Lingüística Aplicada, com 
ênfase em Linguagem e Tecnologia, atuando principalmente nos seguintes temas: letramento digital, interfaces digitais, metáforas conceptuais, metáforas multimodais, metáforas digitais, formação de professores e leitura.

\section{Como citar este artigo de acordo com as normas da revista?}

NOVAIS, Ana Elisa. Convenções de interfaces digitais e leitura ou: para ler interfaces nos textos. Texto Digital, Florianópolis, v. 16, n. 1, p. 233-265, 2020.

\section{Contribuição de autoria}

Não se aplica.

\section{Financiamento}

Não se aplica.

\section{Consentimento de uso de imagem}

Imagem 1: Recursos semióticos em convenções de interfaces no Windows XP. Fonte: elaborado pela autora.

Imagem 2: Propaganda impressa com área de trabalho. Fonte: (MelchersTravelAgency..., 2010).

Imagem 3: Post do Twitter com menu. Fonte: printscreen do perfil do Twitter@divorciei, 2017.

Imagem 4: Remix com botões de comando em mensagem de sistema. Fonte: Objetos inanimados (2013).

Imagem 5: Cartaz de protesto com mensagem e botões de comando. Fonte: Passos (2014).

Imagem 6: Publicidade impressa com metáfora digital ARRASTAR. Fonte: Veja (2016).

Imagem 7: Publicidade com menu de contexto em uso. Fonte: (Alunos da UFF..., 2007).

\section{Aprovação de comitê de ética em pesquisa}

Não se aplica.

\section{Licença de uso}

Este artigo está licenciado sob a Licença Creative Commons CC-BY. Com essa licença você pode compartilhar, adaptar, criar para qualquer fim, desde que atribua a autoria da obra.

\section{Histórico}

Recebido em: 28/11/2019.

Aprovado em: 03/12/2019. 